\title{
Determination of Epidermal Growth Factor Receptor (EGFR), KRAS and BRAF Mutation in Non Small Cell Lung Cancers Using Biofilm Chip Based Microarray Technology
}

\author{
Özlem Ceren Günizi ${ }^{*}$, Gülay Özbilim² and Mualla Özcan ${ }^{2}$ \\ ${ }^{1}$ Department of Pathology, Medical School of Alanya Alaaddin Keykubat University, Turkey \\ ${ }^{2}$ Department of Pathology, Medical School of Akdeniz University, Turkey
}

*Corresponding author: Dr. Özlem Ceren Günizi, Department of Pathology, Medical School of Alanya Alaaddin Keykubat University, Turkey, Tel: +905322574421

\begin{abstract}
Summary
Background: In this study, it vi cell lung carcinoma.

Methods: 96 lung resection materials; it was examined for the presence of TNM (The TNM Staging System is based on the extent of the tumor ( $T$ ), the extent of spread to the lymph nodes $(\mathrm{N})$, and the presence of metastasis $(\mathrm{M})$ ) stage, smoking, age, sex, tumor differentiation and EGFR, KRAS and BRAF mutations.
\end{abstract}

Results: Of the 96 patients included in the study, 58 were adenocarcinomas, 30 were squamous cell carcinomas (SCC), and 8 were large cell neuroendocrine carcinomas (LCNEC). While EGFR mutation was detected in 14 $(24.1 \%)$ of the adenocarcinoma patients, KRAS mutation was detected in $12(20.6 \%)$ patients. BRAF mutation was observed in 1 patient with adenocarcinoma (1.7\%). KRAS mutation was observed in only 1 of the SCCs (3.3\%). KRAS mutation was observed in 1 of the LCNECs (12.5\%).

EGFR mutation in adenocarcinoma cases was found to be significantly associated with female gender and nonsmoking status. There was no correlation between EGFR mutation and age, stage, tumor size, lymph node metastasis, distant metastasis and differentiation grade. No correlation was found between KRAS mutation and other factors. The BRAF mutation could not be assessed for association because the number of cases monitored was low.

The microarray method we used in our study provided the scanning of the cases in terms of 50 different mutations commonly identified for the EGFR gene, single chip 24 different mutations for KRAS and BRAF gene in a total of 96 cases with NSCLC (Non Squamous Cell Lung Cancer) in three different subtypes at the same time and in a short time. We think our study will be useful in the development of treatment protocols and patient selection.

\author{
Keywords \\ Non-small cell lung carcinoma, EGFR, KRAS, BRAF, \\ Microarray
}

\section{Introduction}

Lung cancer is the most common type of cancer seen in males worldwide and the third most common type in females [1]. 85\% of lung cancers occur in non-small cell external lung carcinomas. Small cell lung carcinomas are seen in $15 \%$. Among non-small cell external lung carcinomas, adenocarcinoma $(40 \%)$, squamous cell carcinoma (30\%) and large cell carcinoma (15\%) subtypes are the most common [1,2].

Over the last 10 years, the life time of patients has been increased thanks to new medicines for lung cancer treatment [3] Krizotinib, Gefitinib, Erlotinib and Monoclonal antibodies, such as nivolumab, pembrolizumab, and atezolizumab have been used to treat lung cancer for last years. In the identification of these drugs, histological type of tumor and presence of mutation is the front plan, and the drug activity depends on the biology of the tumor [4]. EGFR is the most promising oncogen in NSCLC [5]. Some specific EGFR mutations are sensitive to EGFR tyrosine kinase inhibitors [6]. Most commonly small exon 19 deletion (del 19) and exon 21-point mutation (L858R), patients were reported to respond well to EGFR tyrosine kinase treatment [7-9]. KRAS gene mutations are more common in males and adenocarci- 
noma-diagnosed individuals with smoking history [10]. BRAF mutation in NSCLC does not lead to worse prognosis alone, but it is sensitive to tyrosine kinase inhibitors of different classes [11-13].

The frequency of EGFR gene mutation in non-small cell lung carcinomas ranges from 58.30 to $61 \%$ for exon 10 and 36.42 to $39 \%$ for exon 21 [14-16]. The frequency of EGFR gene mutation in adenocarcinomas was from $15.5 \%$ for exon 19 and $19.3 \%$ for exon 21 [17] KRAS mutations in the histologic type of adenocarcinoma occur frequently in $25-30 \%$ of cases [1]. BRAF gene mutations are seen only $1-2 \%$ in lung cancer [18]. Tumor tissue can be heterogeneous due to its genetic structure [19]. The aim of our study is to provide the scanning of the cases in terms of 50 different mutations commonly identified for the EGFR gene, single chip 24 different mutations for KRAS and BRAF gene in a total of 96 cases with NSCLC in three different subtypes at the same time and in a short time. The target of our study is to develop treatment protocols and to be useful in patient selection.

\section{Methods}

In our study, 96 cases with non-small cell lung carcinoma diagnosed between the years 2005 and 2012 were evaluated by our department. Approval for this study was acquired from the Ethics Committee of Medical Scholl of the Akdeniz University (219209of). All cases are surgical resection material. The tissues prepared from the resection material are those fixed with $10 \%$ formalin and embedded in paraffin. The 4 micron thick sections which obtained from the patients paraffin blocks were examined by hematoxylin eosin staining. In the selection of paraffin block, samples were selected which are consisted $80 \%$ of tumor tissue. Among the cases included in the study, 58 are composed of adenocarcinoma, 30 are squamous cell carcinoma and 8 are large cell neuroendocrine carcinoma. The smoking status of the cases was determined by examining the clinical history. Ethics Committee approval has been obtained.

Histologic grade, stage, lymph node metastasis, and distant metastasis analysis according to the 2004 World Health Organization classification were determined by experienced pulmonary pathologists. Histological grade is defined as well, moderately and poorly differentiation for adenocarcinoma and squamous cell carcinoma. The staging was done according to the TNM system. For each case, primary tumor size, regional lymph node involvement, and distant metastasis were assessed.

In our study, the aim was to determine the EGFR, KRAS and BRAF gene mutations with the biofilm microarray method (Infiniti Autogenomics) in 96 cases with NSCLC. INFINITI system Autogenomics Inc. (U.S.) is an automated device based on microchip technology which can be developed by taking into consideration all the current requirements in molecular diagnosis, especially the oncology parameters applied in Molecular Pathology. The INFINITI system is a fully automated, multi-molecular diagnostic platform that uses the unique BioFilmChip Microarray for many qualitative and quantitative proteomic and genomic applications.

The Autogenomics Infiniti ${ }^{\mathrm{TM}}$ EGFR mutation screening kit was used to identify EGFR gene mutations and the Autogenomics Infiniti ${ }^{\text {TM }}$ KRAS-BRAF mutation screening kit was used to identify KRAS-BRAF gene mutations. Kits are designed to identify the most common known mutations that alter protein function. The genomic regions were amplified using a multiplex polymerase chain reaction (PCR) in a thermal cycler. An enzymatic cleanup with shrimp alkaline phosphatase and exonuclease was performed after the multiplex PCR. The INFINITI Analyzer was used for allele-specific primer extension with fluorescently labeled nucleotides, capture by hybridization to the microarray, array scans and signal measurements.

\section{Statistical analysis}

Fisher, Anova, and Pearson Chi square tests were used to analyze the categorical data obtained. Kruskal Wallis test was used for comparison between the three groups. Significance value was obtained $p<0.05$ in statistical analysis.

\section{Results}

The ages of the patients included in the study ranged from 32 to 81 years. The mean age of all patients was 61.5. Of the 96 patients included in the study, 58 $(60.4 \%)$ were adenocarcinomas, 30 (31.3\%) squamous cell carcinomas and 8 (8.3\%) large-cell neuroendocrine carcinomas. The differentiation ratios and stage of the tumors were different (Table 1 and Figure 1). 79 (82.3\%) of the patients were male and $17(17.7 \%)$ were female. Cigarette anamnesis is present in 44 of the patients. 35 of the 44 patients were smoking. Nine patients did not smoke. The smoking history of 52 patients was unknown. There was no significant relationship between smoking and histopathological types.

EGFR mutations were detected in $14(24.1 \%)$ of the patients with adenocarcinoma and 12 (20.6\%) KRAS

Table 1: Distribution of tumor types according to differentiation grades.

\begin{tabular}{|l|l|l|l|}
\hline \multicolumn{4}{|l|}{ Differentiation grade } \\
\hline & Well & Moderately & Poorly \\
\hline Adenocarcinoma & 20 & 21 & 17 \\
& $(34.5 \%)$ & $(36.2 \%)$ & $(29.3 \%)$ \\
\hline SCC & 5 & 12 & 13 \\
\hline Total & $(16.7 \%)$ & $(40.0 \%)$ & $(43.3 \%)$ \\
\hline & 25 & 33 & 30 \\
& $(28.4 \%)$ & $(34.1 \%)$ & $(37.5 \%)$ \\
\hline
\end{tabular}




\section{Distribution of tumor types by stage}

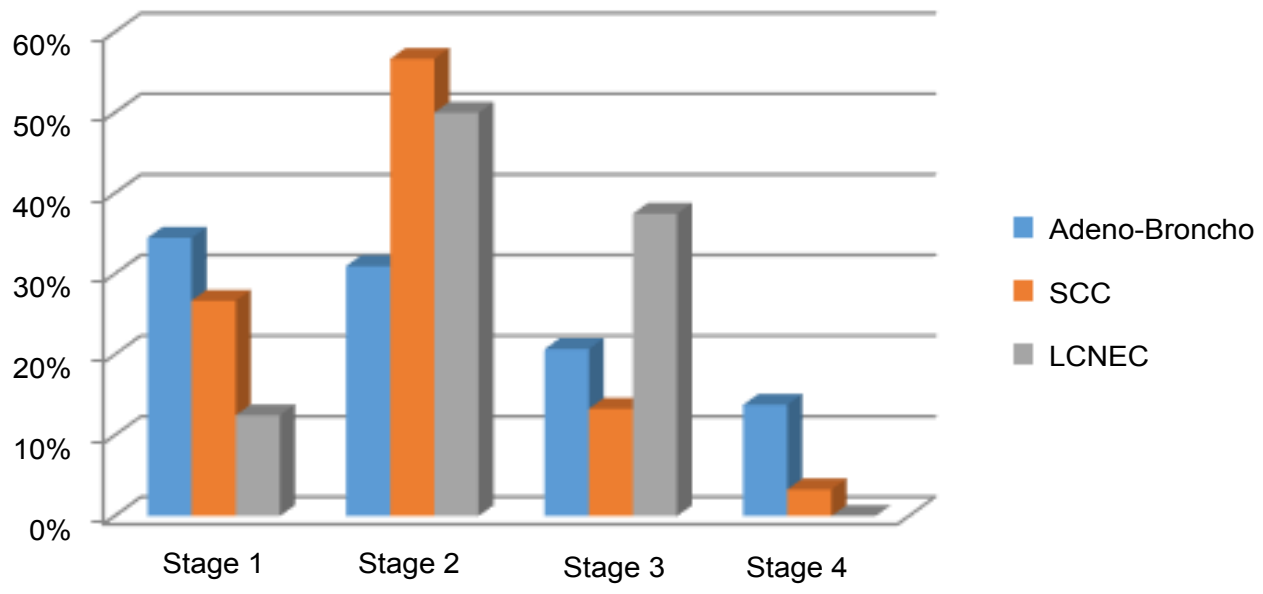

Figure 1: Distribution of tumor types by stage.

Table 2: Tumor and mutation types.

\begin{tabular}{|c|c|c|c|c|c|}
\hline & Mutatio & & & & \\
\hline & NO & EGRF & KRAS & BRAF & TOTAL \\
\hline $\begin{array}{l}\mathrm{A} \text { and } \\
\text { BAC }\end{array}$ & $\begin{array}{l}31 \\
(53.4 \%)\end{array}$ & $\begin{array}{l}14 \\
(24.1 \%)\end{array}$ & $\begin{array}{l}12 \\
(20.7 \%)\end{array}$ & $\begin{array}{l}1 \\
(1.7 \%)\end{array}$ & $\begin{array}{l}58 \\
(100.0 \%)\end{array}$ \\
\hline SCC & $\begin{array}{l}29 \\
(96.7 \%)\end{array}$ & $\begin{array}{l}0 \\
(0.0 \%)\end{array}$ & $\begin{array}{l}1 \\
(3.3 \%)\end{array}$ & $\begin{array}{l}0 \\
(0.0 \%)\end{array}$ & $\begin{array}{l}30 \\
(100.0 \%)\end{array}$ \\
\hline LCNC & $\begin{array}{l}7 \\
(87.5 \%)\end{array}$ & $\begin{array}{l}0 \\
(0.0 \%)\end{array}$ & $\begin{array}{l}1 \\
(12.5 \%)\end{array}$ & $\begin{array}{l}0 \\
(0.0 \%)\end{array}$ & $\begin{array}{l}8 \\
(100.0 \%)\end{array}$ \\
\hline Total & $\begin{array}{l}67 \\
(69.8 \%)\end{array}$ & $\begin{array}{l}14 \\
(14.6 \%)\end{array}$ & $\begin{array}{l}14 \\
(14.6 \%)\end{array}$ & $\begin{array}{l}1 \\
(1.0 \%)\end{array}$ & $\begin{array}{l}96 \\
(100.0 \%)\end{array}$ \\
\hline
\end{tabular}

mutations were detected. BRAF mutation was observed in only 1 patient among the patients. No mutations were found in 31 patients. KRAS mutation was observed in only 1 patient (3.3\%) of patients with squamous cell carcinoma, and no mutation was found in 29 patients $(97.3 \%)$, KRAS mutation was observed in only 1 patient $(12.5 \%)$ in patients with large cell neuroendocrine carcinoma, and no mutation was found in 7 patients (87.5\%) (Table 2).

No significant correlation was found between EGFR mutation and tumor differentiation. There was a significant difference in terms of EGFR mutation between patients with adenocarcinoma, squamous cell carcinoma and large cell carcinoma $(p=0.001)$. Patients with

Table 3: Patients characteristics, adenocarcinoma and bronchoalveolar carcinoma.

\begin{tabular}{|c|c|c|c|c|c|c|c|c|c|}
\hline & Age & G & Tm. & Mut. & $\mathbf{T}$ & $\mathbf{N}$ & M & Stage & Dif. \\
\hline 1 & 62 & $M$ & A & EGFR & T1a & No & MO & $1 \mathrm{~A}$ & $M$ \\
\hline 2 & 70 & $M$ & A & KRAS & $\mathrm{T} 2 \mathrm{~b}$ & N1 & MO & $2 B$ & L \\
\hline 3 & 65 & $M$ & A & EGFR & $\mathrm{T} 2 \mathrm{a}$ & No & M1b & 4 & $M$ \\
\hline 4 & 62 & $M$ & A & - & T4 & N1 & M1b & 4 & L \\
\hline 5 & 56 & $M$ & $A$ & EGFR & $\mathrm{T} 2 \mathrm{~b}$ & No & MO & $2 \mathrm{~A}$ & $L$ \\
\hline 6 & 64 & $M$ & A & - & $\mathrm{T} 2 \mathrm{~b}$ & NO & MO & $2 A$ & $\mathrm{~L}$ \\
\hline 7 & 76 & $F$ & A & - & T2a & No & MO & 1B & $\mathrm{H}$ \\
\hline 8 & 49 & $M$ & A & KRAS & $\mathrm{T} 2 \mathrm{~b}$ & No & M1b & 4 & $\mathrm{H}$ \\
\hline 9 & 80 & $M$ & $A$ & - & T1a & No & MO & $1 \mathrm{~A}$ & $\mathrm{H}$ \\
\hline 10 & 69 & $M$ & A & - & T2a & No & MO & $1 \mathrm{~B}$ & $M$ \\
\hline 11 & 65 & $M$ & A & - & T3 & N1 & M1b & 4 & $M$ \\
\hline 12 & 76 & $M$ & A & - & $\mathrm{T} 2 \mathrm{~b}$ & No & MO & $2 A$ & $\mathrm{H}$ \\
\hline 13 & 64 & $M$ & A & EGFR & T1a & No & M1b & 4 & $M$ \\
\hline 14 & 77 & $M$ & A & - & T3 & N1 & MO & $3 A$ & L \\
\hline 15 & 74 & $F$ & $A$ & BRAF & $\mathrm{T} 4$ & No & MO & $3 A$ & $L$ \\
\hline 16 & 44 & $M$ & A & KRAS & $\mathrm{T} 2 \mathrm{a}$ & No & MO & 1B & $M$ \\
\hline 17 & 70 & $M$ & $A$ & - & $\mathrm{T} 2 \mathrm{a}$ & No & MO & 1B & L \\
\hline 18 & 65 & $M$ & $A$ & - & $\mathrm{T} 2 \mathrm{~b}$ & No & MO & $2 A$ & $\mathrm{~L}$ \\
\hline
\end{tabular}




\begin{tabular}{|c|c|c|c|c|c|c|c|c|c|}
\hline 19 & 77 & $M$ & A & KRAS & T3 & N1 & M0 & $3 A$ & $M$ \\
\hline 20 & 58 & $M$ & A & - & T3 & N1 & MO & $3 A$ & $L$ \\
\hline 21 & 69 & $M$ & A & - & T3 & NO & MO & $2 B$ & $M$ \\
\hline 22 & 71 & $\mathrm{~F}$ & A & - & $\mathrm{T} 1 \mathrm{~b}$ & No & MO & $1 \mathrm{~A}$ & L \\
\hline 23 & 64 & $M$ & A & - & T2a & NO & MO & $1 \mathrm{~B}$ & $M$ \\
\hline 24 & 70 & $M$ & A & - & T1b & NO & MO & $1 \mathrm{~A}$ & $\mathrm{H}$ \\
\hline 25 & 61 & $\mathrm{~F}$ & A & - & T3 & N1 & M0 & $3 A$ & L \\
\hline 26 & 63 & $M$ & A & KRAS & $\mathrm{T} 1 \mathrm{~b}$ & No & MO & $1 \mathrm{~A}$ & $\mathrm{H}$ \\
\hline 27 & 74 & $\mathrm{~F}$ & A & KRAS & $\mathrm{T} 2 \mathrm{~b}$ & No & MO & $2 A$ & $\mathrm{H}$ \\
\hline 28 & 55 & $\mathrm{~F}$ & A & - & T4 & No & MO & $3 A$ & $\mathrm{H}$ \\
\hline 29 & 71 & $M$ & A & - & T1a & No & MO & $1 \mathrm{~A}$ & $M$ \\
\hline 30 & 57 & $\mathrm{~F}$ & A & - & $\mathrm{T} 2 \mathrm{~b}$ & No & MO & $2 \mathrm{~A}$ & $\mathrm{H}$ \\
\hline 31 & 69 & $F$ & A & EGFR & T2a & N2 & M1b & 4 & $M$ \\
\hline 32 & 77 & $M$ & A & - & T3 & No & MO & $2 B$ & L \\
\hline 33 & 79 & $M$ & A & - & T3 & No & M0 & $2 B$ & $L$ \\
\hline 34 & 60 & $M$ & A & - & $\mathrm{T} 4$ & No & MO & $3 A$ & M \\
\hline 35 & 45 & $M$ & A & KRAS & $\mathrm{T} 1 \mathrm{~b}$ & No & M0 & $1 \mathrm{~A}$ & $M$ \\
\hline 36 & 57 & $\mathrm{~F}$ & A & EGFR & $\mathrm{T} 4$ & No & MO & $3 A$ & $\mathrm{H}$ \\
\hline 37 & 73 & $M$ & A & EGFR & T1b & No & MO & $1 \mathrm{~A}$ & M \\
\hline 38 & 70 & $F$ & A & EGFR & T1b & NO & MO & $1 \mathrm{~A}$ & $\mathrm{H}$ \\
\hline 39 & 53 & $M$ & A & - & T1a & N1 & M1b & 4 & L \\
\hline 40 & 61 & $M$ & A & - & $\mathrm{T} 2 \mathrm{~b}$ & N1 & MO & $2 B$ & $\mathrm{H}$ \\
\hline 41 & 68 & $M$ & A & - & T3 & No & MO & $2 \mathrm{~B}$ & M \\
\hline 42 & 47 & $M$ & A & EGFR & $\mathrm{T} 1 \mathrm{~b}$ & No & MO & $1 \mathrm{~A}$ & $L$ \\
\hline 43 & 65 & $\mathrm{~F}$ & A & EGFR & $\mathrm{T} 2 \mathrm{~b}$ & N2 & MO & $3 A$ & $\mathrm{H}$ \\
\hline 44 & 52 & $M$ & A & KRAS & T1a & No & M1b & 4 & M \\
\hline 45 & 51 & $F$ & A & EGFR & T2a & No & MO & $1 \mathrm{~A}$ & $M$ \\
\hline 46 & 64 & $M$ & A & KRAS & T3 & No & MO & $2 B$ & $\mathrm{H}$ \\
\hline 47 & 80 & $M$ & A & KRAS & T2a & N1 & MO & $2 A$ & L \\
\hline 48 & 53 & $M$ & A & EGFR & $\mathrm{T} 1 \mathrm{~b}$ & N2 & MO & $3 A$ & M \\
\hline 49 & 68 & $M$ & A & EGFR & T3 & No & MO & $2 B$ & $M$ \\
\hline 50 & 70 & $M$ & A & EGFR & $\mathrm{T} 2 \mathrm{a}$ & N1 & MO & $2 A$ & L \\
\hline 51 & 66 & $M$ & BAC & - & $\mathrm{T} 2 \mathrm{~b}$ & No & MO & $2 A$ & $\mathrm{H}$ \\
\hline 52 & 74 & $F$ & BAC & KRAS & $\mathrm{T} 2 \mathrm{a}$ & No & MO & 1B & $M$ \\
\hline 53 & 81 & $F$ & BAC & KRAS & $\mathrm{T} 1 \mathrm{~b}$ & No & MO & $1 \mathrm{~A}$ & $\mathrm{H}$ \\
\hline 54 & 71 & $M$ & BAC & - & T2a & No & MO & 1B & $\mathrm{H}$ \\
\hline 55 & 51 & $M$ & BAC & - & $\mathrm{T} 4$ & No & MO & $3 A$ & $\mathrm{H}$ \\
\hline 56 & 69 & $M$ & BAC & - & $\mathrm{T} 2 \mathrm{~b}$ & No & M0 & $2 A$ & $M$ \\
\hline 57 & 55 & $M$ & BAC & - & T2a & No & Mo & $1 \mathrm{~B}$ & $\mathrm{H}$ \\
\hline 58 & 76 & $M$ & BAC & - & T4 & NO & MO & $3 A$ & $\mathrm{H}$ \\
\hline
\end{tabular}

G: Gender; Tm: Tumor Subtype; Mut: Mutation Property; Dif: Differentiation; A: Adenocarcinoma; BAC: Bronchoalveolar Carcinoma; L: Low; M: Medium; H: High.

adenocarcinoma and squamous cell carcinoma were compared in terms of EGFR mutation and EGFR mutation was significantly higher than adenocarcinoma cases with squamous cell carcinoma $(p<0.001)$. There was no significant difference between the adenocarcinoma group and the large cell neuroendocrine carcinoma group in terms of EGFR mutation. EGFR mutation was more frequent in female patient group $(p=0.001)$. EGFR mutation was more frequently observed in the non-smoking group $(p=0.016)$. There was no correlation between EGFR mutation and the stages of patients and $T, N, M$ values.

There was no significant relationship between KRAS mutation and age and sex. Patients with adenocarcinoma and squamous cell carcinoma were compared in terms of KRAS mutation. KRAS mutation was significantly higher in the adenocarcinoma group than in the 
squamous cell carcinoma group $(p=0.007)$. No significant difference was found between the adenocarcinoma group and the large cell neuroendocrine carcinoma group in terms of KRAS mutation. No comparison was made between the squamous cell carcinoma group and the large cell neuroendocrine carcinoma group due to inadequate sampling in terms of KRAS mutation. There was no correlation between KRAS mutation and patients' stage, $T, N, M$ values and tumor differentiation (Table 3, Table 4 and Table 5).

Among 96 patients, BRAF mutation was observed in a woman with only adenocarcinoma. However, this group could not be included in the statistical study due to inadequate sampling.

Table 4: Patients characteristics, squamous cell carcinomas (SCC).

\begin{tabular}{|c|c|c|c|c|c|c|c|c|c|}
\hline & Age & G & Tm. & Mut. & $\mathbf{T}$ & $\mathbf{N}$ & M & Stage & Dif. \\
\hline 1 & 51 & $M$ & SCC & - & T3 & NO & MO & $2 B$ & L \\
\hline 2 & 50 & $M$ & SCC & - & T4 & $\mathrm{N} 1$ & MO & $3 A$ & $\mathrm{H}$ \\
\hline 3 & 54 & $M$ & SCC & - & T4 & NO & MO & $3 A$ & M \\
\hline 4 & 62 & $M$ & SCC & - & T3 & No & M0 & $2 B$ & $M$ \\
\hline 5 & 69 & $M$ & SCC & - & T3 & NO & MO & $2 B$ & $M$ \\
\hline 6 & 63 & $\mathrm{~F}$ & SCC & - & $\mathrm{T} 2 \mathrm{~b}$ & No & MO & $2 A$ & $M$ \\
\hline 7 & 57 & $M$ & SCC & - & T3 & NO & MO & $2 B$ & L \\
\hline 8 & 75 & $M$ & SCC & - & $\mathrm{T} 2 \mathrm{a}$ & NO & MO & 1B & $M$ \\
\hline 9 & 70 & $M$ & SCC & - & T1a & No & MO & $1 \mathrm{~A}$ & $M$ \\
\hline 10 & 60 & $M$ & SCC & KRAS & T3 & No & MO & $2 B$ & $M$ \\
\hline 11 & 58 & $M$ & SCC & - & T3 & No & M0 & $2 B$ & $\mathrm{~L}$ \\
\hline 12 & 58 & $M$ & SCC & - & T3 & $\mathrm{N} 1$ & MO & $3 A$ & L \\
\hline 13 & 73 & $M$ & SCC & - & T1b & No & MO & $1 \mathrm{~A}$ & L \\
\hline 14 & 64 & $M$ & SCC & - & $\mathrm{T} 2 \mathrm{~b}$ & NO & MO & $2 A$ & M \\
\hline 15 & 79 & $M$ & SCC & - & $\mathrm{T} 2 \mathrm{~b}$ & NO & MO & $2 A$ & $\mathrm{~L}$ \\
\hline 16 & 72 & $M$ & SCC & - & T1b & NO & MO & $1 \mathrm{~A}$ & $\mathrm{H}$ \\
\hline 17 & 65 & $M$ & SCC & - & T1a & $\mathrm{N} 1$ & MO & $2 \mathrm{~A}$ & $\mathrm{~L}$ \\
\hline 18 & 61 & $M$ & SCC & - & T3 & No & MO & $2 B$ & $M$ \\
\hline 19 & 67 & $M$ & SCC & - & T2a & $\mathrm{N} 1$ & M1b & 4 & $\mathrm{~L}$ \\
\hline 20 & 32 & $M$ & SCC & - & $\mathrm{T} 2 \mathrm{a}$ & $\mathrm{N} 1$ & M0 & $2 A$ & $\mathrm{H}$ \\
\hline 21 & 62 & $M$ & SCC & - & $\mathrm{T} 2 \mathrm{~b}$ & NO & MO & $2 \mathrm{~A}$ & $M$ \\
\hline 22 & 68 & $\mathrm{~F}$ & SCC & - & T1a & No & M0 & $1 \mathrm{~A}$ & $M$ \\
\hline 23 & 60 & $M$ & SCC & - & T3 & NO & MO & $2 B$ & L \\
\hline 24 & 65 & $M$ & SCC & - & $\mathrm{T} 2 \mathrm{~b}$ & $\mathrm{~N} 1$ & MO & $2 B$ & $M$ \\
\hline 25 & 63 & $M$ & SCC & - & $\mathrm{T} 2 \mathrm{~b}$ & No & M0 & $2 \mathrm{~A}$ & $\mathrm{H}$ \\
\hline 26 & 64 & $M$ & SCC & - & T1a & No & MO & $1 \mathrm{~A}$ & L \\
\hline 27 & 46 & $M$ & SCC & - & $\mathrm{T} 2 \mathrm{~b}$ & No & M0 & $2 A$ & $\mathrm{H}$ \\
\hline 28 & 62 & $M$ & SCC & - & T2a & No & MO & 1B & L \\
\hline 29 & 61 & $M$ & SCC & - & $\mathrm{T} 2 \mathrm{a}$ & No & MO & 1B & L \\
\hline 30 & 72 & $\mathrm{~F}$ & SCC & - & $\mathrm{T} 4$ & NO & MO & $3 A$ & L \\
\hline
\end{tabular}

Table 5: Patients characteristics, Large cell neuroendocrine carcinoma (LCNC).

\begin{tabular}{|l|l|l|l|l|l|l|l|l|}
\hline & Age & G & Tm. & Mut. & T & N & M & Stage \\
\hline $\mathbf{1}$ & 50 & M & LCNC & - & T4 & N0 & M0 & 3A \\
\hline $\mathbf{2}$ & 56 & M & LCNC & - & T1b & N0 & M0 & 1A \\
\hline $\mathbf{3}$ & 62 & M & LCNC & - & T2b & N0 & M0 & 2A \\
\hline $\mathbf{4}$ & 56 & M & LCNC & - & T2a & N1 & M0 & 2A \\
\hline $\mathbf{5}$ & 58 & M & LCNC & - & T2a & N2 & M0 & 3A \\
\hline $\mathbf{6}$ & 66 & M & LCNC & KRAS & T3 & N0 & M0 & 2B \\
\hline $\mathbf{7}$ & 56 & M & LCNC & - & T2b & N2 & M0 & 3A \\
\hline $\mathbf{8}$ & 58 & M & LCNC & - & T2a & N1 & M0 & 2A \\
\hline
\end{tabular}


Adenocarcinoma, squamous cell carcinoma and large cell neuroendocrine carcinoma diagnosed in a total of 96 cases, were not seen together in two different mutations.

\section{Discussion}

In males, $22 \%$ of cancer-related deaths and $15 \%$ of females are due to lung cancer [1]. The etiologic causes of lung cancer are cigarette smoking and the presence of genetic predisposition is also suggested. Current carcinogens in cigarette smoke can lead to genetic mutation by binding to specific regions of DNA. It has been shown that people with lung cancer in their family have 2-5 times more risk of cancer than other people. Damage to genes controlling cell proliferation is the main mechanism of cancer development and can occur as a result of activation of oncogenes or inactivation of tumor suppressor genes [20,21]. EGFR is a transmembrane protein with tyrosine kinase activity. KRAS protein is an activator that develops resistance to the EGFR signaling pathway. KRAS is the most frequently mutated oncogene in lung adenocarcinoma and a member of the RAS family of GTPases. It is activated through GTP binding and once GTP-bound, can trigger multiple signalling transduction pathways and impact cellular processes, about proliferation, cell survival and metabolism. KRAS is typically mutated in human cancer through missense mutations on codons that alter its protein conformation. The BRAF gene encodes a protein with serine-threonine kinase activity that is involved in the mitogen activated protein kinase intracellular signaling pathway (MAPKs). The amino acid residues that specifically encode the kinase domain of BRAF are 457-717. The activation loop of the kinase is located within the residues 59-600, which interact with the phosphate-binding loop keeping the kinase locked. Once the activation loop is phosphorylated, BRAF can also phosphorylate and thus activate the mitogenactivated 2 kinase 1 and 2 (MAP2K 1/2) signaling pathway. This gene controls cell division by effecting its activity on Kras. Gene mutation for BRAF is seen in 1-2\% of lung cancers. It has been shown that the presence of KRAS and BRAF mutations in these patients lead to treatment resistance, while patients treated with the EGFR mutations respond well to treatment [11-13,22]. Although the BRAF mutation alone does not lead to poor prognosis, it is sensitive to tyrosine kinase inhibitors of different classes $[12,13]$.

It has been reported in literature that Asian, non-smoker, female, adenocarcinoma cases with EGFR mutation respond better to treatment $[23,24]$. In treatment, Gefitinip, Erlotinip and monoclonal antibodies such as Cetuximab are used as tyrosine kinase inhibitors targeting the ATP binding pocket of EGFR gene and. Feng $Q$, et al. found more EGFR mutations in the patient group, especially those younger than 60 years, non-smokers, women and adenocarcinomas [25]. The tyrosine kinase activity of the EGFR gene is provided by exons 18-21. The most common EGFR gene mutations in the studies are the in-frame deletions in exon 19 and the L858R point mutation in exon 21 (14). The most common deletion in exon 19 is 747-leucine-749.glutamic acid deletion, which accounts for $44 \%$ of all EGFR mutations. The L858R mutation in exon 21 constitutes $41 \%$ of all EGFR mutations. The deletions and duplications in exon 20 constitute $5 \%[26,27]$. Activating mutations in the EGFR gene affect not only the response to treatment but also the survival time at the same time. In our study, according to literature, EGFR mutation was found significantly higher in adenocarcinoma patient group than other tumor types. One of the 14 EGFR mutations detected is the L858Arg mutation at exon 21, one of them was Leu792Pro mutation in exon 19. The remaining 12 EGFR mutations were seen in exon 19 again.

EGFR and KRAS mutation association was reported to be $5 \%$ in studies conducted [28]. In one study, 99 (32.9\%) of 301 patients had EGFR mutations and 14 (4.7\%) KRAS mutations were detected, but no correlation was found between the two mutations $[29,30]$. Ohashi, et al. showed that the presence of ectopic NRAS or BRAF mutation in cells expressing the highly sensitive EGFR mutation confers resistance to EGFR tyrosine kinase inhibitor treatment [22]. The BRAF inhibitors vemurafenib, dabrafenib, and sorafenib are used for treatment in NSCLC. We did not detect KRAS and BRAF gene mutations in our study with EGFR mutations.

In the literature, the frequency of EGFR mutation in adenocarcinoma cases is reported to be $10-40 \%[31,32]$. Yeen, et al. had studies involving 484 non-small cell lung cancer patients, EGFR mutation was significantly higher in female patients $(60.6 \%)$ and adenocarcinoma $(47.1 \%)$ subtypes [33]. We found EGFR mutation in 14 of the 58 adenocarcinoma cases $(24.1 \%)$ in our study. EGFR mutation is associated with female gender, non-smoking status and adenocarcinoma subtype, TNM stage status is evaluated as unrelated [34-36]. We could not find any significant relationship between EGFR mutation, female gender, adenocarcinoma, non-smoker group and age, stage, tumor size, lymph node metastasis, distant metastasis and differentiation grade.

In the etiology of lung cancer it is often accused of various carcinogens including smoking. It has been observed that lung cancer seen in the non-smoking group is more likely to be younger than the smoker group, and that it is in the subtype of women and adenocarcinoma. KRAS mutation has been reported to be more common in the adenocarcinoma subtype [37]. Smoking specific nitric amines in cigarettes have been shown to induce KRAS gene mutations. Kim, et al. in a large study of adenocarcinomas, they found no association between KRAS mutation frequency and smoking [38]. Adenocarcinoma diagnosed patients with mutations in the KRAS gene has shown resistance to conventional chemotherapy, as 
well as high risk of recurrence and death postoperatively [11]. In adenocarcinoma histologic type, KRAS mutations are frequently seen in $5-40 \%$ and in our study, KRAS mutation was observed in 12 (20.6\%) cases in 58 adenocarcinoma cases [10,39]. 12 KRAS mutations were observed in codons 12 and 13 in exon 2 which were monitored in patients with adenocarcinoma. 5 of these cases were G12 V, 4 of these cases G12C, 2 of these cases G12D and 1 of these cases were G13C subgroup observed. We could not find any significant relationship between KRAS mutation and age, sex, smokers, disease stage, tumor size, lymph node metastasis, distant metastasis and differentiation grade in our study.

In the NSCLC, high-order KRAS mutation was detected in the adenocarcinoma group based on the biofilmbased method [40]. In our study, KRAS mutation was found to be significantly higher in the adenocarcinoma group than in the SCC group. Sasaki, et al. said there was no significant relationship between BRAF mutation and gender, age, tumor stage and smoking status, but BRAF mutation was found to be significantly higher in smoker group in adenocarcinoma patients group [41]. In our study; BRAF mutation was observed in only 1 case with adenocarcinoma and there were no female patients and no smoking history.

BRAF mutations were most frequently found in the literature as point mutations in exon 15 and BRAF mutations were most frequently detected in codon 600 (V600E) by substitution of valine and glutamate amino acids $[18,42]$. Among our cases, BRAF V600E1 subtype mutation was observed in 1 case with adenocarcinoma.

Different molecular techniques are used in studies on mutation screening in solid tumors. The methods used to examine the genetic structure of tumor tissue should have a high mutation detection limit. With the Sanger method, DNA sequence analysis can only detect $20-25 \%$ mutation; This ratio is given as $5 \%$ for pyrosequence, and as $1 \%$ for real-time PCR. Tsiatis, et al. compared the strip test, pyrosequence and sanger sequences in a study they conducted to determine the KRAS gene mutation; as a result, the mutation detection limit of strip test was $1 \%$, limit of pyrosequence was $5 \%$ and of limit of sanger sequence method was 20-25\% [19].

Tumor tissue shows a heterogeneous structure due to its genetic. For this reason, the sensitivity of the methods used to detect even the very low mutation needs to be high and reliable $[43,44]$. The microarray method is more sensitive in detecting small changes in gene expression than real time PCR and Northern blot analysis $[45,46]$. The analyzes of the data we obtained in our study are in accordance with the results of the analyzes in previous studies and showed the reliability of our method.

\section{References}

1. Bray F, Ferlay J, Soerjomataram I, Siegel RL, Torre LA, et al. (2018) Global cancer statistics 2018: Estimates of incidence and mortality worldwide for 36 cancers in 185 countries. CA Cancer J Clin 68: 394-424.

2. Travis WD (2011) Pathology of Lung Cancer. Clin Chest Med 32: 669-692.

3. Sandler A, Gray R, Perry MC, Brahmer J, Schiller JH, et al. (2006) Paclitaxel-carboplatin alone or with bevacizumab for non-small-cell lung cancer. N Engl J Med 355: 2542-2550.

4. Reck M, Heigener DF, Mok T, Soria JC, Rabe KF (2013) Management of non-small-cell lung cancer: Recent developments. Lancet 382: 709-719.

5. Yang JC, Wu YL, Schuler M, Sebastian M, Popat S, et al. (2015) Afatinib versus cisplatinbased chemotherapy for EGFR mutation-positive lung adenocarcinoma (LUX-Lung 3 and LUX-Lung 6): Analysis of overall survival data from two randomised, phase 3 trials. Lancet Oncol 16: 141-151.

6. Hu J, Han Y, Wang J, Liu Y, Zhao Y, et al. (2018) Discovery of selective EGFR modulator to inhibit L858R/T790M double mutants bearing a N-9-Diphenyl-9H-purin-2-amine scaffold. Bioorg Med Chem 26: 1810-1822.

7. Lynch TJ, Bell DW, Sordella R, Gurubhagavatula S, Okimoto RA, et al. (2004) Activating mutations in the epidermal growth factor receptor underlying responsiveness of nonsmall-cell lung cancer to gefitinib. N Engl J Med 350: 21292139.

8. Paez JG, Jänne PA, Lee JC, Tracy S, Greulich H, et al. (2004) EGFR mutations in lung cancer: Correlation with clinical response to gefitinib therapy. Science 304: 14971500.

9. Pao W, Miller V, Zakowski M, Doherty J, Politi K, et al. (2004) EGF receptor gene mutations are common in lung cancers from "never smokers" and are associated with sensitivity of tumors to gefitinib and erlotinib. Proc Natl Acad Sci U S A 101: 13306-13311.

10. Okudela K, Woo T, Kitamura H (2010) KRAS gene mutations in lung cancer: Particulars established and issues unresolved. Pathology International 60: 651-660.

11. Zhou B, Tang C, Li J (2017) k-RAS mutation and resistance to epidermal growth factor receptor-tyrosine kinase inhibitor treatment in patients with nonsmall cell lung cancer. J Can Res Ther 13: 699-701.

12. Linardou $H$, Dahabreh IJ, Kanaloupiti $D$, Siannis $F$, Bafaloukos D, et al. (2008) Assessment of somatic KRAS mutations as a mechanism associated with resistance to EGFR-targeted agents: A systematic review and metaanalysis of studies in advanced non-small-cell lung cancer and metastatic colorectal cancer. Lancet Oncol 9: 962-972.

13. Pratilas CA, Hanrahan AJ, Halilovic E, Persaud Y, Soh J, et al. (2008) Genetic predictors of MEK dependence in nonsmall cell lung cancer. Cancer Res 68: 9375-9383.

14. Gazdar AF (2009) Activating and resistance mutations of EGFR in non small cell lung cancer: role in clinical response to EGFR tyrosine kinase inhibitors. Oncogene 28: 24-31.

15. Riely J, Pao W, Pham D, Li AR, Rizvi N, et al. (2006) Clinical Course of patients with non-small cell lung cancer and epidermal growth factor receptor exon19 and exon 21 mutations treated with gefitinib or erlotinib. Clin Cancer Res 12: 839-844.

16. Wang ZF, Ren SX, Li W, Gao GH (2018) Frequency of the acquired resistant mutation T790 $\mathrm{M}$ in non-small cell lung cancer patients with active exon 19Del and exon 21 L858R: 
A systematic review and meta-analysis. BMC Cancer 18: 148.

17. Rosell R, Moran T, Queralt C, Porta R, Cardenal F, et al. (2009) Screening for Epidermal Growth Factor Receptor Mutations in Lung Cancer. N Engl J Med 361: 958-967.

18. Schmid K, OehI N, Wrba F, Pirker C, Filipits M (2009) EGFR/ KRAS/BRAF mutations in primary lung adenocarcinomas and corresponding locoregional lymph node metastases. Clin Cancer Res 15: 4554-4560.

19. Tsiatis A, Norris-Kirby A, Rich RG, Hafez MJ, Gocke $C D$, et al. (2010) Comparisons of sanger sequencing, pyrosequencing and melting curve analysis for the detection of KRAS mutations. J Mol Diagn 12: 425-432.

20. Soh J, Okumura N, Lockwood W, Yamamato H, Shigematsu $\mathrm{H}$, et al. (2009) Oncogene mutations, copy number gains and mutant allele spesific imbalance (MASI) frequently occur together in tumor cells. PLOS One 4: e7464.

21. Cruz C, Tanove L, Matthay R (2011) Lung cancer: Epidemiology, etiology and prevention. Clin Chest Med 32: 605-644.

22. Ohashi K, Sequist LV, Arcila ME, Moran T, Chmelecki $\mathrm{J}$, et al. (2012) Lung cancers with acquired resistance to EGFR inhibitors occasionally harbor BRAF gene mutations but lack mutations in KRAS, NRAS, or MEK1. Proc Natl Acad Sci USA 109: E2127-E2133.

23. Li C, Fang R, Sun Y, Han X, Li F, et al. (2011) Spectrum of oncogenic driver mutations in lung adenocarcinomas from East Asian never smokers. Plos One 6: e28204.

24. Sun Y, Ren Y, Fang Z, Li C, Fang R, et al. (2010) Lung adenocarcinoma from East Asian never-smokers is a disease largely defined by targetable oncogenic mutant kinases. J Clin Oncol 28: 4616-4620.

25. Feng Q, Li XH, Chen Z, He JS, Wang CX, et al. (2011) Epidermal growth factor receptor gene mutations and clinicopathologic correlation in 309 patients with nonsmall cell lung cancer. Zhonghua Bing Li Xue Za Zhi 40: 660-663.

26. Cappuzzo F, Hirsch FR, Rossi E, Bartolini S, Ceresoli $\mathrm{GL}$, et al. (2005) Epidermal growth factor receptor gene and protein and Gefitinib sensitivity in non-small cell lung cancer J Nall Cancer Inst 97: 643-655.

27. Dacic S (2008) EGFR assays in lung cancer. Adv Anat Pathol 15: 241-247.

28. Takeda M, Okamoto I, Fujita $\mathrm{Y}$, Arao T, Ito H, et al. (2010) De novo resistance to epidermal growth factor receptortyrosine kinase inhibitors in EGFR mutation-positive patients with non-small cell lung cancer. J Thorac Oncol 5: 399-400.

29. Sun LN, Luan HL, Zang FL, Wang M, Dong N, et al. (2010) Relationship between EGFR and K-ras mutations and clinicopathological characteristics and response to erlotinib treatment in 301 Chinese patients with non-small cell lung cancer. Zhonghua Zhong Liu Za Zhi 32: 667-670.

30. Chiosea S, Shuai Y, Cieply K, Nikiforova MN, Dacic S (2010) EGFR fluorescence in situ hybridization-positive lung adenocarcinoma: incidence of coexisting KRAS and BRAF mutations. Hum Pathol 41: 1053-1060.

31. Riely GJ, Politi KA, Miller VA (2006) Update on epidermal growth factor receptor mutations in non-small cell lung cancer. Clin Cancer Res 12: 7232-7241.

32. Jackman DM, Yeap BY, Sequist LV (2006) Exon 19 deletion mutations of epidermal growth factor receptor are associated with prolonged survival in non-small cell lung cancer patients treated with gefitinib or erlotinib. Clin Cancer Res 12: 3908-3914.

33. Yeen TNS, Pathmanathan R, Shiran MS, Zaid FAA, Cheah YK (2013) Detection of epidermal growth factor receptor mutations in formalin fixed paraffin embedded biopsies in Malaysian non-small cell lung cancer patients. J Biomed Sci 20: 22.

34. Yang SY, Yang TY, Chen KC, Li YJ, Hsu KH, et al. (2011) EGFR L858R mutation and polymorphisms of genes related to estrogen biosynthesis and metabolism in neversmoking female lung adenocarcinoma patients. Clin Cancer Res 17: 2149-2158.

35. Wang F, Fu S, Tang T, Deng L, Zhang X, et al. (2011) Relationship between mutations of epidermal growth factor receptor gene and clinicopathologic features of non-small cell lung cancers. Zhonghua Bing Li Xue Za Zhi 40: 664666.

36. Fan MJ, Li HG, Lü ZQ, Zhang HZ, Shen XM (2011) Relationship of epidermal growth factor receptor gene mutations, clinicopathologic features and prognosis in patients with non-small cell lung cancer. Zhonghua Bing $\mathrm{Li}$ Xue Za Zhi 40: 679-682.

37. Kaseda K, Asakura K, Kazama A, Ozawa Y (2017) Clinicopathological and prognostic features of surgically resected pathological stage I lung adenocarcinoma harboring epidermal growth factor receptor and K-ras mutation. Thoracic Cancer 8: 229-237.

38. Kim HR, Ahn JR, Lee JG, Bang DH, Ha SJ, et al. (2013) The impact of cigarette smoking on the frequency of and qualitative differences in KRAS mutations in Korean patients with lung adenocarcinoma. Yonsei Med J 54: 865874.

39. Riely GJ, Marks J, Pao W (2009) KRAS mutations in nonsmall cell lung cancer. Proc Am Thorac Soc 6: 201-205.

40. Kriegshauser G, Fabjani G, Ziegler B, ZöchbauerMüller S, End A, et al. (2011) Biochip-based detection of KRAS mutation in non-small cell lung cancer. Int $\mathrm{J}$ Mol Sci 12: 8530-8538.

41. Sasaki H, Shitara M, Yokota K, Okuda K, Hikosaka Y, et al. (2012) Braf and erbB2 mutations correlate with smoking status in lung cancer patients. Exp Ther Med 3: 771-775.

42. Paik $P$, Arcila ME, Fara $M$, Sima CS, Miller VA, et al. (2011) Clinical characteristics of patients with lung adenocarcinomas harboring BRAF mutations. J Clin Oncol 29: 2046-2051.

43. Bilitewski U (2009) DNA microarrays: An introduction to the technology. Methods Mol Biol 509: 1-14.

44. Jancik S, Drabek J, Berkovcova J, Xu YZ, Stankova M, et al. (2012) A comparison of Direct sequencing, Pyrosequencing, High resolution melting analysis, TheraScreen DxS, and the K-ras StripAssay for detecting KRAS mutations in non small cell lung carcinomas. J Exp Clin Cancer Res 31: 79.

45. Angulo B, Conde E, Suárez-Gauthier A, Plaza C, Martínez $R$, et al. (2012) A comparison of EGFR mutation testing methods in lung carcinoma: direct sequencing, real-time PCR and immunohistochemistry. PLoS One 7: e43842.

46. French D, Smith A, Powers MP, Wu AH (2011) KRAS mutation detection in colorectal cancer by a commercially available gene chip array compares well with Sanger sequencing. Clin Chim Acta 412: 1578-1581. 